\title{
MODELING OF OHIYA CLAY FOR CERAMIC TILES PRODUCTION
}

\author{
NWANKWOJIKE B. NDUKA ${ }^{1}$, ONWUKA S. OSINACHI ${ }^{2}$, IKECHUKWU E. PRINCE ${ }^{3}$, IBEH I. \\ MATTHEW $^{4}$, ANIUGA CHUKWUMA ${ }^{5} \&$ EDEH C. JOHN ${ }^{6}$ \\ 1, 2, 3, 4,6 Department of Mechanical Engineering, Michael Okpara University of Agriculture, Umudike, Nigeria \\ ${ }^{5}$ Department of Marketing, Michael Okpara University of Agriculture, Umudike, Nigeria
}

\begin{abstract}
A simulation model for producing different types/qualities of ceramic tiles from ohiya clay-feldspar-quartztalc-pyrophyllite mix was developed in this study to advance industrial scale utilization of abundant natural clay reserve at Ohiya in Abia State of Nigeria. This clay mineral remained stranded in the hands of local artisans and small scale investors due to associated defects in most ceramics produced from it using existing/foreign formulations. The effects of varied formulations of ohiya clay, feldspar, quartz, talc and pyrophyllite on the linear shrinkage, modulus of rupture, water absorption, apparent porosity and bulk density of their associated tiles were empirically assessed and simulated using response surface based desirability analysis. The developed simulation predicts optimal settings of these materials for producing any desired tile. Experimental results revealed the simulation's prediction accuracy of over $99 \%$ and 47:24:3:20:6 as optimal mix of ohiya clay, feldspar, pyrophyllite, talc and quartz for standard floor tiles production. The respective linear shrinkage, modulus of rupture, water absorption, apparent porosity and bulk density of $8.08 \%, 52.59 \mathrm{~kg} / \mathrm{cm} 3,2.48 \%, 5.01 \%$ and $2.09 \mathrm{~g} / \mathrm{cm}^{3}$ exhibited by tiles developed using this product design conformed to ISO/NIS set standards. Production of standard floor tiles of $0.0929 \mathrm{~m}^{2}$ with this optimal formulation yielded zero defect and $4.64 \%$ savings. Hence, adoption of the developed simulation for producing any desired type/quality of ceramic tile from ohiya clay is recommended
\end{abstract}

KEYWORDS: Ceramic Tile, Ohiya Clay, Optimal Formulation, Simulation Model

Received: Jun 06, 2020; Accepted: Jun 26, 2020; Published: Jul 28, 2020; Paper Id.: IJMPERDJUN2020497

\section{INTRODUCTION}

Ceramic tile is an indispensable material in modern housing because it is hard-wearing and adaptable to any home décor style with less maintenance. It also very easy to clean and constitutes an efficient way of maintaining consistent temperature in a room (Effting et al., 2007). Hence, it's ever increasing demand and importation in Nigeria to meet the local need (Massaad, 2016). The raw materials mostly used for ceramic tile production in this country include clay, feldspar, silica/quartz, talc and pyrophyllite (RMRDC, 2009). Clay material provides binding, plasticity, light colouration, good density level, mechanical and rheological flow characteristics in the tiles. Feldspar constitutes a common fluxing material for ceramic bodies which gives it a glossy finish and plays a vital role in its attainment of vitrified and high mechanical resistance. Silica reduces its shrinkage and increases the fired body's whiteness while talc enhances the fluxing action, whiteness and modulus of rupture of fired tile body while 
pyrophyllite reduce thermal expansion firing temperature of the clay body. Natural deposits of these raw materials abound in all geopolitical zones of Nigeria and some records showed their viability for ceramics applications (RMRDC, 2009; Iyasara et al., 2014). However, the works of Azunna et al.(2017) and Onyekuru et al.(2018)which showed that most natural clay deposits in Eastern Nigeria are not compatible with the imported ones revealed why investors are scared of over 74.38 million metric tons of natural clay deposit at Ohiya in Umuahia, Abia State of Nigeria. Investors are scared of full industrial scale application of ohiya clay for ceramic tile production despite the unlimited good market potential for tiles in Nigeria because most of the ceramic products made from it are often characterized by defects such as cracks, specks, pin hole and rough edge. This is because the ceramics body were composed from formulations designed base on the foreign clays which doesn't match some natural deposits in Nigeria.

Ohiya clay predominantly kaolinite with silica and alumina as principal oxides (Mark and Onyemaobi, 2009; Azunna et al., 2017; Onyekuru et al., 2018). Its viability of ohiya clay for refractory, oil bleaching and electrical insulation applications were shown in Mark et al.(2011), Ndukwe et al.(2013), Cajetan et al.(2015) and Chima et al.(2017)but none of them established specific designs/models for developing the products from it. Thereforedeveloping a design for producing different types/qualities of tiles from ohiya clay in line with International Organization for Standardization/Nigerian Industrial Standard (ISO/NIS)specifications will be a gateway in reechoing investors' interest in this untapped clay deposit. Ceramics tiles are classified based on surface of application in building as floor, wall, partition and roofing tiles. Although, these tiles are generally meant for good aesthetics, the apparent porosity, bending strength/modulus of rupture, bulk density, linear shrinkage and water absorption rating desired of each differs according to their usage/design life (NIS, 2000; ISO, 2018). Since any ceramic tile that fall short of ISO/NIS rating peculiar to its surface of application in even one of these parameters constitutes substandard product and some of the parameters improve while others deteriorate as the raw materials setting of the tile body varies, a desirabilityfunction based multifactor-response simulation/optimizer lends itself to this study (NIST/SEMATECH, 2013).Successful applications of this tool in product formulation was obvious in the optimal mix of jackfruit-sauce, Itopride HClmatrix tablets, sweetenersugar yoghurt,chickpea gel and rice husk-saw dust ceiling board established by Pitiporn et al.(2011), Anirbandeep et al.(2013), Xuyan et al.(2014), Canet et al.(2015) and Madu et al.(2018)respectively. Hence, this work applied desirability function based response surface method to develop a simulation model producing different types/qualities of ceramic tiles from ohiya clay-feldspar-quartz-talc-pyrophyllite mixin accordance with end users' desire.

\section{MATERIALS AND METHODS}

This study involves experimental determination of the limits at which quantities of ohiya clay, feldspar, pyrophyllite, talc and quartz (factors) influence quality attributes/properties (responses) of ceramic tiles developed from their mix. The clay used was obtained directly from the natural clay deposit site at Ohiya in Umuahia, Nigeria while feldspar, pyrophyllite, talc and quartz were sourced from Umuahia industrial market. The quality attributes evaluated include apparent porosity, bulk density, linear shrinkage, modulus of rupture, and water absorption rate. The results of this test were used for investigating the concurrent impacts of main effects/interactions of the factors on the responses using ahalf blocked central composite design at fivefactor levels $(-\alpha,-1,0,+1,+\alpha)$. The $-1,0$ and +1 represents the low, middle and upper levels of the factors. Axial point $(\alpha)$ levels $(-2,+2)$ and 33 number of experimental runs (tests) used in this analysis were determined from the following relations (NIST/SEMATECH, 2013).

$$
\alpha=2(k-c p)^{-4}
$$




$$
N=k^{2}+2 k+c p
$$

Where $N, k$ and $c p$ are number of runs, factorsand central point replications respectively. The data obtained were analyzed with iterative fitting/selection of best mathematical functions relating each of the responses and the factors using residual plots aided backward elimination method. The developed models were simulated for the materials mix prediction using Minitab response optimizer with desired setting of the tile's quality attributes as target. The prediction accuracy of the simulation was confirmed experimentally with ISO/NIS specifications for ceramics floor tile as set targets. The standard limits for apparent porosity, bulk density, linear shrinkage, modulus of rupture, and water absorption rate of a ceramic floor tile are -20 to $20 \%, \leq 2.3 \mathrm{~g} / \mathrm{cm}^{2}, 7-10 \%, \geq 37.45 \mathrm{~kg} / \mathrm{cm}^{2}$ and 1.1 to $5 \%$ respectively (NIS, 2000).

The tile test samples were developed and assessed in accordance with ISO 10545-4 procedures. All the responses were evaluated with rectangular samples of $8 \mathrm{~cm} \times 4 \mathrm{~cm} \times 1.5 \mathrm{~cm}$ except that of rupture modulus which measured $9.5 \mathrm{~cm} \times 2 \mathrm{~cm} \times 1.5 \mathrm{~cm}$. Each sample was composed with different mix of ohiya clay, feldspar, pyrophyllite, talc and quartz in accordance with experimental design before moulding with compressing pressure of $50 \mathrm{MPa}$. This is followed by its drying to a constant weight with applied convection heat of $110^{\circ} \mathrm{C} \pm 5^{\circ} \mathrm{C}$ at the surface, glazing/firing for one hour at a rate of $3^{\circ} \mathrm{C} / \mathrm{min}$ up to $600^{\circ} \mathrm{C}$ and $5^{\circ} \mathrm{C} / \mathrm{min}$ from $600^{\circ} \mathrm{C}$ to $1150^{\circ} \mathrm{C}$ and cooling to ambient temperature. Apparent porosity, bulk density and water absorption rate of the specimen were evaluated by determining its dry weight $\left(W_{d a}\right)$ which involves drying it for 12 hours at $105^{\circ} \mathrm{C}$ before cooling. This is followed by suspending it in a vessel of boiling water for 1 hour, cooling to room temperature while still immersed in the water and measuring its weight in water after 24 hours $\left(W_{s w}\right)$ before weighing in air to determine its saturated weight $\left(W_{\text {sat }}\right)$. Apparent porosity $\left(P_{a}\right)$, bulk density $\left(D_{b}\right)$ and water absorption rate $\left(W_{A}\right)$ of each test sample were computed as follows;

$$
\begin{aligned}
& \left.P_{a}, \%\right)=\left\{\frac{W_{s a t}-W_{d a}}{W_{s a t}-W_{s w}}\right\} 100 \\
& D_{b}\left(\mathrm{~g} / \mathrm{cm}^{3}\right)=\frac{W_{d a}}{W_{s a t}-W_{s w}} \\
& W_{A}(\%)=\frac{W_{s a t}-W_{d a}}{W_{d a}} 100
\end{aligned}
$$

The linear shrinkage $\left(L_{S}\right)$ and modulus of rupture $(\delta)$ of specimen were computed from the following relations after determining its mechanical strength/breaking loads $(P)$ using an electrical transversal strength machine and distance between its supports $(L)$. The fired $\left(L_{f}\right)$ and green $\left(L_{g}\right)$ lengths of the specimen as well as height $(H)$ and width $(b)$ of its broken edges were measured with vernier caliper.

$$
\begin{gathered}
L_{S}(\%)=\frac{100\left(L_{g}-L_{f}\right)}{L_{g}} \\
\delta\left(\mathrm{kg} / \mathrm{cm}^{2}\right)=\frac{3 P L}{2 b H^{2}}
\end{gathered}
$$

\section{RESULTS AND DISCUSSIONS}

The experimental results of the materials limits and multifactor-response evaluation of ceramics tile production from ohiya clay-feldspar-pyrophyllite-talc-quartz mix are shown in Table 1 and 2 respectively while equations (8) to (12) constitute 
functions derived for predicting apparent porosity, bulk density, linear shrinkage, modulus of rupture, and water absorption rate of the tile body.

Table 1: Limits of Materials for producing ceramics tile from ohiya clay

\begin{tabular}{|c|c|c|c|}
\hline \multirow{2}{*}{ S/No. } & Factor Description & \multicolumn{2}{|c|}{ Factor Levels (kg) } \\
\cline { 3 - 4 } & & High $(+\mathbf{1})$ & Low (-1) \\
\hline 1 & Ohiya clay $(C)$ & 65 & 55 \\
\hline 2 & Feldspar $(f)$ & 20 & 10 \\
\hline 3 & Pyrophyllite $(p)$ & 18 & 8 \\
\hline 4 & Talc $(t)$ & 17 & 7 \\
\hline 5 & Quartz $(q)$ & 20 & 10 \\
\hline
\end{tabular}

Table 2: Multifactor-response analysis of ceramic tiles from ohiya clay

\begin{tabular}{|c|c|c|c|c|c|c|c|c|c|c|c|}
\hline \multicolumn{2}{|c|}{ Design Order } & \multicolumn{5}{|c|}{ Factor Setting } & \multicolumn{5}{|c|}{ Responses } \\
\hline Standard & Run & $\begin{array}{c}\mathrm{C} \\
(\boldsymbol{k g})\end{array}$ & $\begin{array}{c}\mathbf{t} \\
(\boldsymbol{k g})\end{array}$ & $\begin{array}{c}\mathbf{p} \\
(\boldsymbol{k} \boldsymbol{g})\end{array}$ & $\begin{array}{c}\mathbf{f} \\
(\boldsymbol{k g})\end{array}$ & $\begin{array}{c}\mathbf{Q} \\
(\boldsymbol{k g})\end{array}$ & $\begin{array}{l}\boldsymbol{L}_{\boldsymbol{S}} \\
(\%)\end{array}$ & $\begin{array}{l}W_{A} \\
(\%)\end{array}$ & $\begin{array}{c}\boldsymbol{P}_{\boldsymbol{a}} \\
(\%)\end{array}$ & $\begin{array}{c}D_{b} \\
\left(\mathrm{~g} / \mathrm{cm}^{3}\right)\end{array}$ & $\begin{array}{c}\delta \\
(\mathrm{kg} \\
\left./ \mathrm{cm}^{2}\right) \\
\end{array}$ \\
\hline 8 & 1 & 65.00 & 17.00 & 18.00 & 10.00 & 10.00 & 13.40 & 1.94 & 3.80 & 1.96 & 48.46 \\
\hline 9 & 2 & 55.00 & 7.00 & 8.00 & 20.00 & 10.00 & 11.10 & 1.93 & 3.78 & 1.96 & 48.97 \\
\hline 17 & 3 & 60.00 & 12.00 & 13.00 & 15.00 & 15.00 & 13.40 & 1.60 & 3.14 & 1.97 & 49.22 \\
\hline 14 & 4 & 65.00 & 7.00 & 18.00 & 20.00 & 10.00 & 14.00 & 1.28 & 2.52 & 1.98 & 53.06 \\
\hline 5 & 5 & 55.00 & 7.00 & 18.00 & 10.00 & 10.00 & 17.40 & 1.39 & 2.74 & 1.97 & 52.73 \\
\hline 16 & 6 & 65.00 & 17.00 & 18.00 & 20.00 & 20.00 & 15.10 & 1.34 & 2.64 & 1.97 & 54.69 \\
\hline 7 & 7 & 55.00 & 17.00 & 18.00 & 10.00 & 20.00 & 11.50 & 1.78 & 3.49 & 1.96 & 49.66 \\
\hline 18 & 8 & 60.00 & 12.00 & 13.00 & 15.00 & 15.00 & 12.00 & 1.57 & 3.08 & 1.98 & 48.33 \\
\hline 10 & 9 & 65.00 & 7.00 & 8.00 & 20.00 & 20.00 & 11.80 & 1.15 & 2.26 & 1.97 & 55.23 \\
\hline 15 & 10 & 55.00 & 17.00 & 18.00 & 20.00 & 10.00 & 12.00 & 1.41 & 2.78 & 1.96 & 54.65 \\
\hline 1 & 11 & 55.00 & 7.00 & 8.00 & 10.00 & 20.00 & 12.40 & 2.04 & 4.00 & 1.98 & 47.97 \\
\hline 21 & 12 & 60.00 & 12.00 & 13.00 & 15.00 & 15.00 & 12.20 & 1.50 & 2.27 & 1.96 & 54.88 \\
\hline 13 & 13 & 55.00 & 7.00 & 18.00 & 20.00 & 20.00 & 12.30 & 2.07 & 4.05 & 1.98 & 46.63 \\
\hline 19 & 14 & 60.00 & 12.00 & 13.00 & 15.00 & 15.00 & 12.40 & 1.50 & 2.56 & 1.55 & 54.36 \\
\hline 4 & 15 & 65.00 & 17.00 & 8.00 & 10.00 & 20.00 & 12.20 & 1.98 & 3.46 & 1.46 & 46.23 \\
\hline 20 & 16 & 60.00 & 12.00 & 13.00 & 15.00 & 15.00 & 11.10 & 1.87 & 3.64 & 1.85 & 38.74 \\
\hline 3 & 17 & 55.00 & 17.00 & 8.00 & 10.00 & 10.00 & 13.45 & 1.64 & 3.02 & 1.95 & 45.23 \\
\hline 6 & 18 & 65.00 & 7.00 & 18.00 & 10.00 & 20.00 & 14.90 & 2.69 & 5.23 & 1.97 & 48.45 \\
\hline 2 & 19 & 65.00 & 7.00 & 8.00 & 10.00 & 10.00 & 14.20 & 1.38 & 2.71 & 1.98 & 52.33 \\
\hline 11 & 20 & 55.00 & 17.00 & 8.00 & 20.00 & 20.00 & 6.70 & 0.78 & 1.54 & 1.99 & 55.46 \\
\hline 22 & 21 & 60.00 & 12.00 & 13.00 & 25.00 & 15.00 & 13.70 & 1.61 & 3.17 & 1.97 & 50.36 \\
\hline 12 & 22 & 65.00 & 17.00 & 8.00 & 20.00 & 10.00 & 13.80 & 1.65 & 3.24 & 1.97 & 46.78 \\
\hline 31 & 23 & 60.00 & 12.00 & 13.00 & 15.00 & $20.00 *$ & 12.80 & 1.94 & 3.81 & 1.96 & 51.12 \\
\hline 28 & 24 & 60.00 & 12.00 & $36.00 *$ & 15.00 & 15.00 & 13.60 & 2.51 & 4.90 & 1.95 & 48.34 \\
\hline 23 & 25 & $110.00^{*}$ & 12.00 & 13.00 & 15.00 & 15.00 & 12.89 & 1.64 & 3.25 & 1.95 & 47.88 \\
\hline 26 & 26 & 60.00 & $34.00 *$ & 13.00 & 15.00 & 12.00 & 12.42 & 1.96 & 3.43 & 1.97 & 50.98 \\
\hline 32 & 27 & 60.00 & 12.00 & 13.00 & 15.00 & $40.00 *$ & 11.90 & 1.99 & 3.89 & 1.96 & 49.84 \\
\hline 29 & 28 & 60.00 & 12.00 & 13.00 & $20.00 *$ & 15.00 & 15.20 & 4.26 & 8.18 & 1.92 & 46.26 \\
\hline 30 & 29 & 60.00 & 12.00 & 13.00 & $40.00 *$ & 15.00 & 13.43 & 2.05 & 3.39 & 1.97 & 51.23 \\
\hline 25 & 30 & 60.00 & $14.00^{*}$ & 13.00 & 15.00 & 15.00 & 16.60 & 3.41 & 6.46 & 1.94 & 46.45 \\
\hline 33 & 31 & 60.00 & 12.00 & 13.00 & 15.00 & 15.00 & 11.70 & 2.82 & 5.49 & 1.95 & 47.87 \\
\hline 24 & 32 & $110.00^{*}$ & 12.00 & 13.00 & 15.00 & 15,00 & 13.90 & 1.10 & 2.17 & 1.98 & 52.87 \\
\hline 27 & 33 & 60.00 & 12.00 & $16.00 *$ & 15.00 & 15.00 & 11.50 & 1.15 & 2,27 & 1.48 & 49.16 \\
\hline
\end{tabular}

*Axial points

$$
\begin{aligned}
& P_{a}=3.411+311.83 f+235.55 f^{2} \\
& D_{b}=1.9183+13.303 p
\end{aligned}
$$




$$
\begin{aligned}
& L_{S}=12.915+62.87 \mathrm{C}+8.02 \mathrm{t}+17.155 \mathrm{p}+11.46 \mathrm{f}+12.20 \mathrm{q}+1241.324 C \mathrm{f}+1025.103 C \mathrm{q} \\
& \delta=22.155 f+49.831 \\
& W_{A}=1.935+13.405 f+359.478 C^{2}+230.775 f^{2}
\end{aligned}
$$

Analysis of residuals associated with developed functions (Table 3) indicated their aptness for further analysis since constant variance assumption is not violated, hence, their simulation using response optimizer for predicting optimal levels

\begin{tabular}{|c|c|c|c|c|c|c|c|c|}
\hline Source & DF & Adj SS & Adj MS & F-Value & P-Value & $\mathbf{S}$ & R-sq & R-sq(adj) \\
\hline $\boldsymbol{P}_{a}$ & 3.00 & 24.81 & 8.27 & 7.75 & 0.00 & 0.13 & 98.90 & 98.76 \\
\hline$f$ & 1.00 & 9.64 & 9.64 & 9.04 & 0.01 & & & \\
\hline$f * f$ & 1.00 & 5.45 & 5.45 & 5.10 & 0.03 & & & \\
\hline Error & 29.00 & 30.94 & 1.07 & & & & & \\
\hline Lack-of-Fit & 24.00 & 29.75 & 1.24 & 5.20 & 0.04 & & & \\
\hline$D_{b}$ & 1.00 & 0.88 & 0.88 & 5.20 & 0.03 & 0.13 & 99.36 & 99.09 \\
\hline$p$ & 1.00 & 0.88 & 0.88 & 5.20 & 0.03 & & & \\
\hline Error & 31.00 & 0.52 & 0.02 & & & & & \\
\hline Lack-of-Fit & 26.00 & 0.31 & 0.01 & 0.27 & 0.09 & & & \\
\hline$L s$ & 1.00 & 74.87 & 10.70 & 7.53 & 0.00 & 0.19 & 98.83 & 98.82 \\
\hline$C$ & 1.00 & 7.90 & 7.90 & 5.56 & 0.03 & & & \\
\hline$t$ & 1.00 & 15.22 & 15.22 & 10.71 & 0.00 & & & \\
\hline$p$ & 1.00 & 16.58 & 16.58 & 11.68 & 0.00 & & & \\
\hline$f$ & 1.00 & 12.03 & 12,03 & 8.47 & 0.01 & & & \\
\hline$q$ & 1.00 & 7.54 & 7.54 & 5.31 & 0.03 & & & \\
\hline$C * f$ & 1.00 & 8.78 & 8.78 & 6.18 & 0.02 & & & \\
\hline$C * q$ & 1.00 & 6.83 & 6.83 & 4.81 & 0.04 & & & \\
\hline Error & 25.00 & 35.51 & 1.42 & & & & & \\
\hline Lack-of-Fit & 20.00 & 30.96 & 1.55 & 1.70 & 0.03 & & & \\
\hline$\delta$ & 1.00 & 49.15 & 49.15 & 4.16 & 0.05 & 0.44 & 99.84 & 99.00 \\
\hline$f$ & 1.00 & 49.15 & 49.15 & 4.16 & 0.05 & & & \\
\hline Error & 31.00 & 36.59 & 11.80 & & & & & \\
\hline Lack-of-Fit & 26.00 & 19.56 & 7.52 & 0.22 & 0.05 & & & \\
\hline$W_{A}$ & 5.00 & 8.41 & 1.68 & 6.90 & 0.00 & 0.41 & 98.11 & 97.98 \\
\hline$C$ & 1.00 & 0.03 & 0.03 & 0.12 & 0.03 & & & \\
\hline$f$ & 1.00 & 2.43 & 2.43 & 10.01 & 0.00 & & & \\
\hline$C * C$ & 1.00 & 1.33 & 1.33 & 5.45 & 0.03 & & & \\
\hline$f * f$ & 1.00 & 1.63 & 1.63 & 6.67 & 0.02 & & & \\
\hline Error & 27.00 & 6.58 & 0.24 & & & & & \\
\hline Lack-of-Fit & 22.00 & 6.48 & 0.30 & 15.09 & 0.00 & & & \\
\hline
\end{tabular}
of ohiya clay, feldspar, quartz, talc and pyrophyllite that will jointly satisfy a given set of ceramics tile responses.

Table 3: Residual analysis of the developed prediction models

The developed simulation predicted optimal coded factors mix ratio of -2:2:-2:1.8788:-1.7980 (Figure 1) which implies actual ohiya clay-feldspar-pyrophyllite-talc-quartz mix ratio of 47:24:3:20:6 for standard floor tile formulation. It also revealed $52.69 \mathrm{~kg} / \mathrm{cm}^{2}, 7.99 \%, 2.07 \mathrm{~g} / \mathrm{cm}^{3}, 4.98 \%$ and $2.5 \%$ as the modulus of rupture, linear shrinkage, bulk density, apparent porosity and water absorption rate expected of floor tiles produced from this optimal formulation. Comparative analysis of these prediction with experimental values of quality indicators of the floor tiles (Figure 2) developed from this optimal design revealed prediction error of -0.81 to $0.96 \%$ and the measured parameters conformed to NIS/ISO specifications (Table 4). Application of this product design in $0.0929 \mathrm{~m}^{2}$ floor tile formulation yielded $4.64 \%$ savings without defect. Table 5 showed one thousand five hundred and twenty-nine naira $(\$ 1,529.00)$ as total cost of producing one packet of this size of floor tile while one thousand six hundred naira (\$1600) constitutesits prevailing market price in 
Umuahia. Therefore, the simulation model developed is recommended for predicting optimal formulation of any desired type/quality of ceramics tile from ohiya clay-feldspar-pyrophyllite-talc-quartz mix.

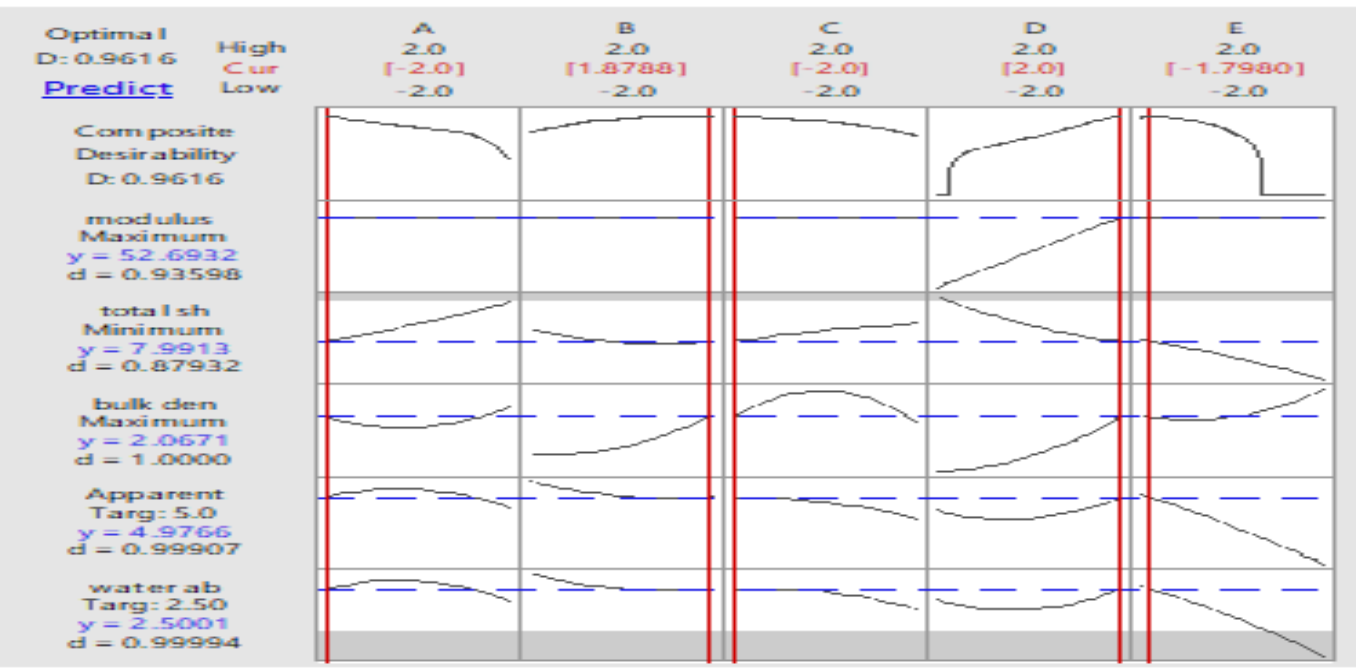

Figure 1: Simulation of ohiya clay for ceramic floor tile production

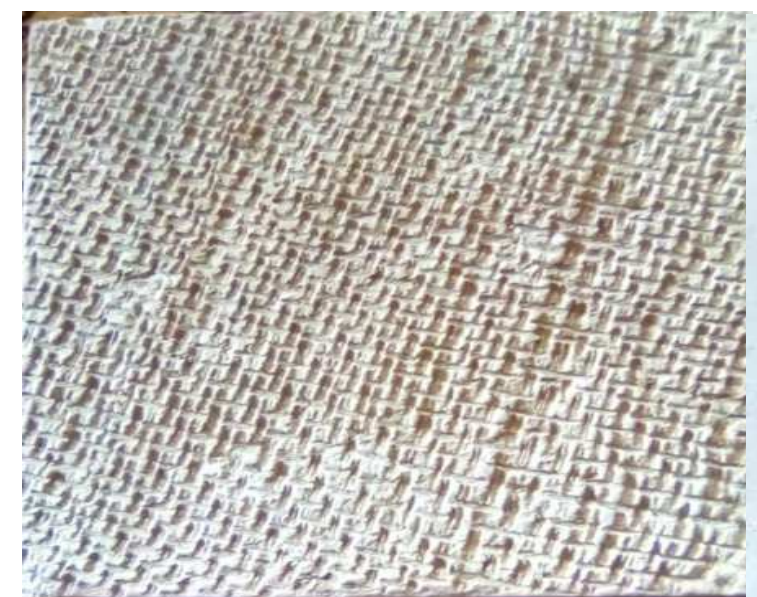

Figure 2: Floor tiles developed from ohiya clay based optimal formulation

Table 4: Analysis of prediction accuracy of the simulation for tile production from ohiya clay

\begin{tabular}{|c|c|c|c|c|c|}
\hline \multirow[t]{2}{*}{ S/No. } & \multirow[t]{2}{*}{ Response Description } & \multicolumn{2}{|c|}{ Response Levels } & \multirow{2}{*}{$\begin{array}{l}\text { Prediction } \\
\text { Error }(\%)\end{array}$} & \multirow{2}{*}{$\begin{array}{c}\text { ISO } \\
\text { Specification }\end{array}$} \\
\hline & & Actual & Predicted & & \\
\hline 1 & Modulus of rupture $\left(\mathrm{kg} / \mathrm{cm}^{2}\right)$ & 52.59 & 52.69 & -0.19 & $\geq 37.45$ \\
\hline 2 & Linear shrinkage (\%) & 8.05 & 7.99 & 0.75 & $7-10$ \\
\hline 3 & Bulk density $\left(\mathrm{g} / \mathrm{cm}^{3}\right)$ & 2.09 & 2.07 & 0.96 & $\leq 2.3$ \\
\hline 4 & Apparent porosity (\%) & 5.01 & 4.98 & 0.60 & $-20-+20$ \\
\hline 5 & Water absorption (\%) & 2.48 & 2.50 & -0.81 & $1.1-5.0$ \\
\hline
\end{tabular}

Table 5: Cost analysis of standard floor tile from ohiya clay

\begin{tabular}{|c|c|c|c|c|}
\hline S/N & Description & $\begin{array}{c}\text { Quantity } \\
(\mathbf{k g})\end{array}$ & $\begin{array}{c}\text { Unit Price } \\
\text { K }\end{array}$ & $\begin{array}{c}\text { Amount } \\
\text { K }\end{array}$ \\
\hline 1. & Clay & 3.00 & 20.00 & 90.00 \\
\hline 2. & Feldspar & 1.00 & 160.00 & 240.00 \\
\hline 3. & Pyrophyllite & 1.50 & 140.00 & 154.00 \\
\hline 4 & Talc & 1.00 & 165.00 & 165.00 \\
\hline 5 & Quartz & 1.80 & 100.00 & 180.00 \\
\hline 4. & Labour cost & & & 700.00 \\
\hline \multicolumn{2}{|c|}{ Total } & & $\mathbf{1 , 5 2 9 . 0 0}$ \\
\hline
\end{tabular}




\section{CONCLUSIONS}

A simulation model used for formulating ohiya clay, feldspar, quartz-talc and pyrophyllite mix into ceramic tiles without defects which often characterized ceramics produced from this clay was developed in this study.Experimental results showed over $99 \%$ prediction accuracy of the model and that floor tiles produced from its prediction conformed to ISO/NIS specifications with $4.64 \%$ savings and zero defect index. Thus, its adoption for large scale production of ceramic tiles from ohiya clay is recommended.

\section{ACKNOWLEDGEMENT}

Tertiary Education Trust Fund, Abuja is highly valued for funding this study

\section{REFERENCES}

1. Anirbandeep B, TinW W\&NavjotS(2013). Formulationdevelopment andoptimizationof sustained release matrix tablet of itopride hcl by response surface methodology and its evaluation of release kinetics, Saudi Pharmaceutical Journal,21(2), 201213.

2. Azunna D E, Chukwu G U, Nwokoma E U \& Akenami A (2017). Evaluation of clay mineral deposits in ohiya, southeast Nigeria using the self-potential method and lithologs, Current Journal of Applied Science and Technology, 22(6), 1- 11.

3. Cajetan $O C$, Ezechukwu O A, Olisakwe C O, Ezendokwelu C E \& Umunna C (2015). Characterization of electrical porcelain insulators from local clays, International Journal of Research - Granthaalayah, 3(1), 26-36.

4. Canet W, Jiménez M J, Fuentes $R$ \& Álvarez M D (2015). Formulation development of a new chickpea gel using response surface methodology and instrumental and sensory data, J Food Process Eng., 38: 271-289.

5. Chima $O$ M, Nwokeocha $T O$, \& Aliegu F N F (2018). Development and characterization of electrical porcelain insulator from local clay materials", Umudike Journal of Engineering and Technology, 4(3), 147 - 151

6. Effting C, Güths $S$ \& Alarcon $O E$ (2007). Evaluation of the thermal comfort of ceramic floor tiles, Materials Research, 10 (3), 301-306.

7. ISO 13006 (2018). Ceramic tiles: Definitions, Classification, Characteristics and Marking, International Organization for Standardization, 1214 Vernier, Geneva.

8. ISO 10545-4 (2018). Ceramic Tiles - Part 3: Determination of Water Absorption, Apparent Porosity, Apparent Relative Density and Bulk Density, International Organization for Standardization, 1214 Vernier, Geneva.

9. ISO 10545-4 (2018).Ceramic Tiles - Part 4: Determination of Modulus of Rupture and Breaking Strength, International Organization for Standardization, 1214 Vernier, Geneva.

10. Iyasara A, Joseph M, Daniel TT \& Azubuike C T, Exploring Ceramic Raw Materials in Nigeria and their Contribution to National Development, American Journal of Engineering Research, 3(2014) 127-134.

11. Madu O G, Nwankwojike B N, Ani O I, Optimal design for rice husk-saw dust reinforced polyester ceiling board American Journal of Engineering Research, 7(2018)6, 11-16.

12. Mark, U. and Onyemaobi, O. (2009). Assessment of the industrial potentials of some Nigerian kaolinitic clay deposits. Inter. Res. J. Sci., Eng. and Tech., 6(1): $77-84$.

13. Mark U, Onyemaobi O, Nwobodo C, Uche R (2011). Evaluation of some refractory characteristics of ohiya and uzuakoli clays, International Journal of Natural and Applied Sciences, 7 (3), 238 - 248. 
14. Massaad CKD (2016). Integrated Set to Open Ceramic Factory, Vanguard business news report of April $21,2016$.

15. Ndukwe O, Nkwocha P, Onyelucheya O (2013). Crude palm kernel oil bleaching with ohiya clay: complications of linearized second order kinetic model, International Journal of Academic Research, 5(3), 232 - 237

16. NIS 427:2000/ICS:91.100.25, Nigerian Industrial Standard for Ceramic Tiles, Standard Organization of Nigeria, Abuja.

17. NIST/SEMATECH (2013).Engineering Statistics-Handbook, National Institute of Standards and Technology, Gaithersburg,. https://doi.org/10.18434/M32189A.

18. Onyekuru S O, Iwuoha P O, Iwuagwu C J, Nwozor K K\& Opara K D (2018). Mineralogical and geochemical properties of clay deposits in parts of southeastern Nigeria, International Journal of Physical Sciences, 13 (14), 217-229

19. PitipornR, WannisaS\&ThanutA. (2011). Optimization of jackfruit sauceformulations using response surface methodology, Kasetsart Journal of Natural Sciences, 43:325 - 334.

20. RMRDC Survey Series 061(2009). Raw Materials Sourcing for Manufacturing in Nigeria, Raw Materials Research and Development Council, Abuja.

21. XuyanY, Yanhua L\&GuohuaH, (2014).Optimization of sweetener formulation insugar-free yoghurt using response surface methodology, Journal of Food, 12(2), 121 - 126.

\section{AUTHOR PROFILE}

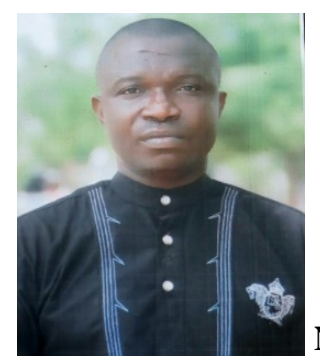

Nwankwojike, Bethrand Nduka is an Associate Professor of Mechanical Engineering at Michael Okpara University of Agriculture, Umudike. He holds B. Eng. M. Eng. Ph. D Degrees in Mechanical/Industrial Engineering \& Management with systems design, development, and modeling/optimization as major research interests. He authored four patents and over seventy technical papers in journals and conference proceedings. He received Best Mathematical Modeling of Raw Materials Processing Equipment Award for the year 2009/2010 from National Mathematical Centre/Raw Materials Research and Development Council, Abuja and Best Engineering Academic Publication Award from Committee of Deans of Engineering and Technology of Nigerian Universities in 2018. Engr. Dr. Nwankwojike is a registered Engineer and a member of many professional bodies.

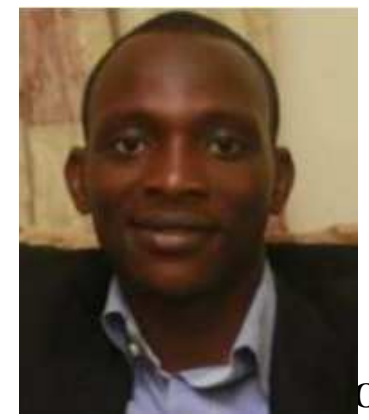

Onwuka Osinachi Stanley is a registered Engineer and lecturer in the Department of Mechanical Engineering at Michael Okpara University of Agriculture, Umudike. He holds B. Eng. and M. Eng. Degrees in Mechanical Engineering with specialization in Design and Production. He a corporate member of Nigeria Society of Engineers with three patents and over twenty-five technical papers in journals and conference proceedings. 


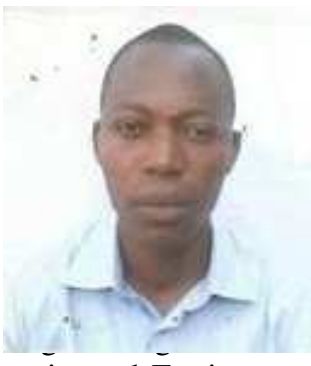

registered Engineer Society of Engineers.

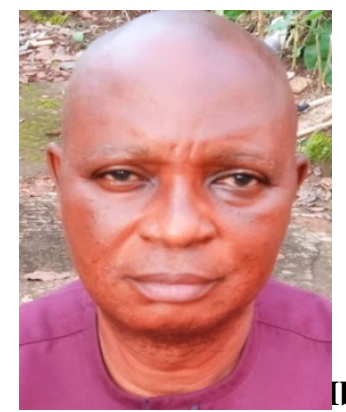

Ikechukwu Prince Echereobia is a Master of Engineering degree student in Mechanical/Material supervision of Dr. Nwankwojike at Michael Okpara University of Agriculture, Umudike. He is a ith B. Eng. degree in Materials and Metallurgical Engineering and a corporate member of Nigeria

Ibeh Matthew Imagwuike is a lecturer in the Department of Mechanical Engineering at Michael Okpara University of Agriculture, Umudike. He holds B. Eng. and M. Eng. Ph.D Degrees in Mechanical Engineering with special interests in Materials, Industrial and Systems Engineering. He a member of many professional bodies with over fifteen journals articles to his credit.

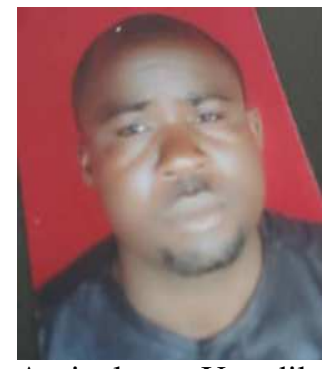

Aniuga Chukwuma is a Lecturer at the Department of Marketing, Michael Okpara University of Agriculture, Umudike, He holds B.Sc., M.Sc., Ph.D in Marketing and Proficiency Certificate with special interest in product planning, product development and product innovation. Dr. Aniuga Chukwuma is an Associate Member National Institute of Marketing of Nigeria (CHARTERED) and Graduate Member of Nigerian Institute of Management (CHARTERED). He has over twenty journals and conference proceedings to his credit.

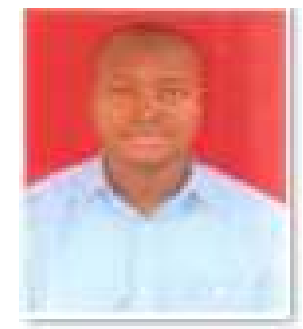

Edeh, John Chijioke is a researcher in the Department of Mechanical Engineering at Michael Okpara University of Agriculture, Umudike, Nigeria. He holds B. Eng. M. Eng. Ph. D Degrees in Design and Production Engineering and an author of over thirty journal articles. Dr. Edeh is a registered Engineer in Nigeria and a member of many professional bodies. His research interests are design, material, machine development, modeling and optimization. 

